\title{
CANDOMBLÉ: RELIGIÃO AFRICANA E CATOLICISMO EM UM JOGO DE ESPELHOS
}

TALL, Emmanuelle Kadya. Le candomblé de Bahia: miroir baroque des mélancolies postcoloniales. Paris: Cerf, 2012. 172 p.

$K_{\text {adyaTall iniciou seu trabalho so- }}$ bre o candomblé da Bahia com uma agenda de pesquisa sociológica bastante tradicional: tratava-se de testar correlações preferenciais entre o culto baiano dos orixás e certas categorias sociais (pescadores, afrodescendentes) e espaços de moradia (áreas pobres e carentes de infraestrutura). A posterior constatação de que o candomblé agregava e respondia à experiência de setores bastante diferenciados da sociedade baiana levou-a a mudar de rumo. Nesse caso, como bem demonstra o livro resultado de sua pesquisa, a mudança implicou uma revisão e mesmo refutação de algumas premissas subjacentes às analises clássicas do candomblé.

De fato, o livro pretende apresentar o candomblé da Bahia em uma chave bastante diferente daquela que tem dominado os estudos clássicos sobre a formação e consolidação dessa religião no Brasil. Em vez de privilegiar a matriz africana no processo de formação do can- domblé, a autora quer iluminar o papel, a seu ver central, do catolicismo nesse processo. Em vez de tomar o candomblé como resultado de realidades previamente constituídas (na África, em Portugal, em terras brasileiras), pretende abordá-lo como emergência do novo em um espaço-tempo de intensa circulação e troca. Conforme a autora, enquanto a primeira abordagem conduz a uma busca pelas origens, esta última direciona a pesquisa para o contexto mesmo do encontro (o Atlântico Sul) em que se forma e ao qual responde o candomblé. Inspirada no trabalho de Paul Gilroy, mas também na obra de intelectuais brasileiros e latino-americanos como Luis Felipe de Alencastro e Bolívar Escheverría, Tall define esse contexto como espaço de uma experiência histórica singular, compartilhada por escravos africanos, colonos portugueses e habitantes nativos das colônias, espaço-tempo marcado pelo tráfico negreiro, pela pregnância do ima- 
ginário barroco e pela experiência, diferencialmente declinada, da nostalgia. Para entender a formação do candomblé e seu papel na sociedade brasileira contemporânea, argumenta Tall, é preciso remontar a essa experiência histórica compartilhada.

Elemento central dessa experiência é o catolicismo da Contrarreforma, com sua ênfase em uma religiosidade barroca que apela aos sentidos e à emoção. Escreve a autora:

No Brasil, o barroco ilustra notavelmente o encontro dos imaginários ameríndio, africano e europeu que se manifesta através de uma apropriação diferenciada e singular das imagens cristãs (p. 137).

Constituindo um universo religioso comum, embora diferencialmente apropriado pelos distintos segmentos da sociedade colonial, o catolicismo da Contrarreforma delineia as possibilidades e o modo pelo qual a tradição africana é recomposta e recriada na colônia. Em sua discussão acerca do papel do catolicismo na configuração do candomblé, Tall rejeita a hipótese do sincretismo de máscara, avançada por Bastide, e propõe, em lugar da metáfora da máscara ("que esconde para preservar"), a metáfora do espelho ("que mostra para preservar"). No candomblé, argumenta, o rito africano espelha o rito católico que, por sua vez, se vê transformado sob o ponto de vista desse outro que o reflete. Nesse jogo de espelhamentos, constituem-se corpos e subjetividades e multiplicam-se os pontos de vista.
O livro está divido em três capítulos, além de uma introdução e conclusão. Os dois primeiros têm como foco a análise de dois rituais de candomblé observados em diversas ocasiões pela autora, ambos realizados em datas marcantes do calendário religioso católico. Dados acerca dos terreiros pesquisados e da trajetória de suas lideranças servem para contextualizar os rituais descritos e junto com essas descrições constituem o grosso do material empírico apresentado. A análise remete esse material para o espaço-tempo do Atlântico Sul e, em especial, para o imaginário barroco característico do catolicismo da Contrarreforma. O último capítulo aprofunda a discussão do barroco, correlacionando-o à experiência e expressão da nostalgia na colônia. Para a autora, é o mundo barroco de nostalgia (pós)colonial que o candomblé reflete.

Vejamos com mais detalhe como o argumento é desenvolvido.

O capítulo que segue a introdução, intitulado "Um pai de santo no Atlântico Sul", analisa o rito que marca o início do ano litúrgico no terreiro de Toluayê, pai de santo com quem a autora manteve relação de forte proximidade ao longo de sua pesquisa no Brasil, chegando mesmo a acompanhá-lo em duas viagens à África (República do Benin). O rito em questão, realizado na data católica do Sábado de Aleluia, "abre" o terreiro, cujas atividades (assim como aquelas de um grande número de casas de candomblé) são regularmente suspensas durante 
a Quaresma. Ilustra, assim, um dos modos pelos quais se relacionam e se compõem, no candomblé baiano, catolicismo e culto africano. Para Tall, não se trata simplesmente de uma acomodação do calendário litúrgico do candomblé ao calendário católico, mas de uma articulação bem mais profunda, segundo a qual o rito católico fornece o quadro geral da cerimônia que se desenrola. Para a autora:

A abertura do ano litúrgico na casa de Toluayê, no sábado de aleluia, isto é, enquanto Jesus Cristo é celebrado pelo silêncio e recolhimento antes de sua ressurreição no dia seguinte, está longe de ser neutra ( $\mathrm{p}$. 57).

A presença definidora, embora oculta, de Jesus Cristo no rito em questão é inferida primeiro por um breve comentário sobre o jejum feito pelo pai de santo no início da festa e, depois, pela referência a Oxalá (orixá da criação, identificado com Senhor do Bonfim) feita pelas equedes do terreiro para despachar (finalizar a possessão) os exus incorporados nos filhos de santo. Isso é suficiente para a autora concluir que o ritual opera segundo

[...] uma lógica de inversão em que a alma de Cristo, enquanto em visita aos infernos - daí o silêncio e recolhimento observados pelos católicos neste dia - é evocada através de mensageiros desordeiros, os exus, que são, no Brasil, associados à figura do diabo... (p.59).
O capítulo seguinte dá continuidade a essa linha argumentativa. Nele é analisado o ritual da Cabeça de Boi, realizado nos terreiros mais tradicionais de Salvador no dia da celebração católica de Corpus Christi. No ritual, o sacrifício de um boi para Oxóssi, orixá caçador, é antecedido por uma missa católica (enquanto em muitos terreiros há um deslocamento dos adeptos à igreja, na casa de pai Dudu, pesquisada pela autora, é o padre que se desloca para celebrar a missa no terreiro). $\mathrm{Na}$ interpretação proposta por Tall, a Eucaristia e, mais particularmente, o fenômeno da transubstanciação fornecem o modelo que conecta esses dois segmentos rituais em uma totalidade englobante, "fazendo-os operar em perfeita sintonia, um com o outro" (p. 92). Assim,

A sequência narrativa, evocando na abertura o sacrifício de Cristo e no fechamento o corpo do sacrificador, indica o sentido da história e funda a genealogia que conecta as duas figuras celebradas. A figura de Cristo como vítima funda o poder do caçador Oxossi e é esta filiação que permite instituir a comunidade de adeptos do candomblé (p.105)

Cabem aqui algumas observações críticas. A autora oferece ao leitor poucos elementos para sustentar sua análise. As conclusões a que chega sobre o papel do modelo católico na estruturação dos dois ritos descritos (conclusões que extrapola, sem maiores mediações, para o candom- 
blé como um todo) são formuladas com base em descrições formais e concisas e sem recurso às interpretações dos atores (Tall parece assumir de antemão que estes últimos estão equivocados porque persuadidos ou interessados na teoria do sincretismo como máscara, que ela mesma deseja negar). Mais significativo ainda, o material apresentado não sustenta a conclusão forte de que o candomblé, profundamente marcado pelo catolicismo emotivo e sensual da Contrarreforma, se constitui enquanto um "espelho barroco das melancolias coloniais" (melancolia vivida tanto pelos africanos, quanto pelos portugueses e indígenas). Para fundamentar sua tese, a autora teria de se dedicar a uma pesquisa histórica séria sobre o candomblé (afinal, a questão que ela enfrenta demanda justamente isso) ou, pelo menos, dialogar diretamente com os autores contemporâneos que o fizeram e que, sem negar o processo de bricolagem de que resultou essa religião, chamam atenção para o papel central de modelos institucionais e práticas religiosas africanas na sua configuração. ${ }^{1}$

Apesar dessas limitações, o livro ilumina conexões importantes no processo formativo do candomblé, lembrando aos estudiosos a necessidade de ir além das fórmulas interpretativas já consagradas para explorar novas facetas desse processo. O papel do imaginário católico barroco na formação da ética e estética características do candomblé baiano é certamente umas dessas facetas que merece mais atenção.

Miriam C. M. Rabelo mcmrabelo@uol.com.br Universidade Federal da Bahia

\footnotetext{
Ver, por exemplo, Luis Nicolau Parés, $A$ formação do candomblé: história e ritual da nação jeje na Bahia, Campinas: Editora da Unicamp, 2006.
} 